\title{
Choosing the Best Investment for Muslims According to Shariah
}

\author{
Dina Fitrisia Septiarini and Dian Fillianti \\ Islamic Economics Departement, Airlangga University, Surabaya, Indonesia \\ dina.fitrisia@gmail.com
}

Keywords: Investment, Islamic Stock, Kruskal-Wallis Test.

\begin{abstract}
Investment is owning one or more assets and usually long term with the hope of gaining profit in the future. The return earned must be proportional to the risk of losses on assets. That is, the higher the risk of assets the higher the expected return of the asset. The purpose of this study is to determine the difference of rate of risk on Islamic stock, Islamic mutual fund, sukuk, 3 months of mudharabah deposit, gold, and property period 2008-2016. It uses quantitative approach by using Kruskal-Wallis test. The sample collecting method used is purposive sampling. This study used secondary data that was collected from official websites of Indonesia Stock Exchange, PT BNP Paribas, Indosat Ooredoo, Bank Syariah Mandiri, Price Gold, and Residential Property Price Index on Makassar. Data used was historical data. The result Kruskal-Wallis test show that there was significant difference of rate of risk on Islamic Stock, Islamic Mutual Fund, Sukuk, Mudharabah deposit, Gold and Property. The result of this study proved that Islamic Stock is better than another type of investments.
\end{abstract}

\section{INTRODUCTION}

The development of Islamic finance institutions in Indonesia is also the development of various sharia investments. Caliph Umar once told the Muslims saying: "Whoever has the money, wants him to invest it and anyone who owns the land wants him to plant it" (Hidayat, 2011:24). The foundation is to extend us to meet the wealth and use it in investing. But the wealth must be accounted to Allah SWT listed in the Qur'an Saba':39 which reads:

Qul 'Inna Robbī Yabsutūr-Rizqo Liman Yasyā'u Min 'Ibādih̄̄ Wayaqdiru Lahū. Wamā 'AnfaqtumMin Syai'in Fahuwwa Yukhlifuhū. Wahuwa Khoyrūr-Rōziqīna.

"Say: Indeed, my Lord extends provision for whom he wills of his servants and restricts (it) for him. But whatever thing you spend (in his cause), He will compensate it and $\mathrm{He}$ is the best of providers. (QS. 34:39, Departemen Agama RI, 1971:690).

According to Al-Mahali (2000: 273), the above verse explains that everyone gives sustenance to his family that is sustenance from Allah SWT. That is, every addition of wealth is always dependent on the will of Allah SWT, so what one gets is a result of pleasure given by Allah SWT.
The research used quantitative approach. The variables used are return, risk, and coefficient of variation.

\subsection{Type and source of data}

Type of data in this research is secondary data. The source of data that can be accessed by www.idx.co.id, PT BNP Paribas, sukuk, www.goldprice.org, www.syariahmandiri.co.id, www.bi.co.id, several other litelature sources related to this research. It make purposive sampling, that analyzed for nine years, so the total data in this research was 54 data data (Indonesia Stock Exchange, 2017), (Gold Price, 2017), (PT. Bank Syariah Mandiri, 2017), (Bank Indonesia, 2017).

\subsection{Operational definition}

Rate of risk is a measure of the relative deviation of a distribution as the standard deviation ratio with the estimated value for the value of the distribution. It data can be obtained from the expected return and risk in quarterly investment instrument period 2008-2016 using data ratio and it is time series. 


\section{LITERATURE REVIEW}

Table 1: Difference between Islamic Stock, Islamic Mutual Fund, Sukuk Ijarah, Gold, Mudharabah deposit, and Property.

\begin{tabular}{|l|l|l|l|l|l|}
\hline \multicolumn{1}{|c|}{ Islamic Stock } & \multicolumn{1}{|c|}{ Islamic Mutual Fund } & \multicolumn{1}{|c|}{ Sukuk Ijarah } & \multicolumn{1}{|c|}{$\begin{array}{c}\text { Gold } \\
\text { deposit }\end{array}$} & Pro-perty \\
\hline $\begin{array}{l}\text { Inclusion of } \\
\text { Company }\end{array}$ & $\begin{array}{l}\text { Systematic risk and } \\
\text { un-systematic risk }\end{array}$ & $\begin{array}{l}\text { Certificate of } \\
\text { ownership proof }\end{array}$ & $\begin{array}{l}\text { Wealth } \\
\text { Preser- } \\
\text { vation }\end{array}$ & Saving & Immobi-lity \\
\hline No & Yes & 3 years & No & $3,6,12$ month & No \\
\hline Divdends & NAV & $\begin{array}{l}\text { Payable monthly } \\
\text { interest on deposits }\end{array}$ & $\begin{array}{l}\text { Profit } \\
\text { rising } \\
\text { price }\end{array}$ & Profit Sharing & Profit rising price \\
\hline Can be traded & Can be traded & $\begin{array}{l}\text { Can't, redemption } \\
\text { option }\end{array}$ & $\begin{array}{l}\text { Can be } \\
\text { traded }\end{array}$ & Can't be traded & Can be traded \\
\hline No & No & No & No & Max 2 Bilion & No \\
\hline
\end{tabular}

* More literature

The objective of all investment is capital gain, which is the positive difference between selling price and purchase price of the issuer because the company earns a profit (Samsul, 2006: 160). If there are two investments which have the same rate of return but different rate of risks, then the investors prefer the lower risk investment. Similarly, with the same rate of return risk, investors prefer the investment with higher risk that will face the same crisis. However, when encountering two investments that have rate of return equal to the rate of risk, it should be calculated the result of each investment.

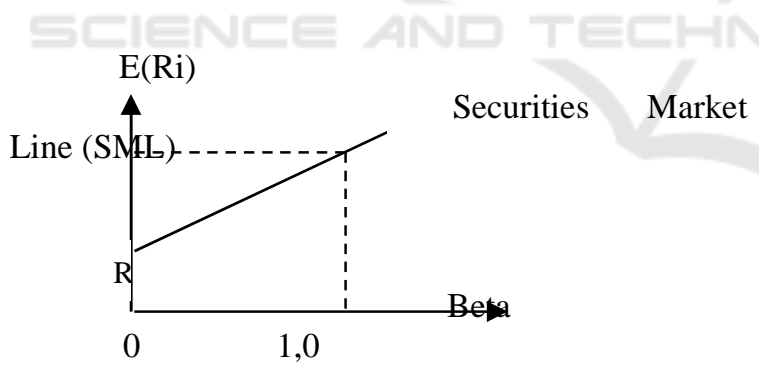

Figure 1: Trade off Return and Risk.

Yusoff, et.al (2010), investments on commercial properties are more attractive compared to investment on banking Institutions. Mensi, et.al (2015), GCC stock market and global investors can realize both risk diversification benefits and downside risk reductions during tranquil and downturn periods by including gold or Dow Jones Islamic Wold Emerging Market (DJIWEM) in their portfolios but not the Tbills. Mansor and Ishaq (2011), Islamic mutual fund portfolios were dependent on the market portfolio of which the former portfolio was closely mirrored to the market movement in relation to the latter portofolio.

Here is the model of the return realized, expected return, risk, and coefficient of variation equation of each investment instrument:

1. Return Realized

$$
\mathrm{R}_{\mathrm{I}}=\frac{\mathrm{P} \mathrm{C}_{\mathrm{t}}-\mathrm{P} \mathrm{P} \mathrm{I}-1}{\mathrm{I}-1}
$$

2. Expected Return

$$
\mathrm{E}(\mathrm{Ri})=\sum_{\mathrm{j}-i}^{\mathrm{n}} \frac{\mathrm{R} \quad \mathrm{R}}{\mathrm{r}}
$$

3. Risk

$$
\sigma_{i}=\sqrt{\sum_{i=1}^{n} \frac{\left[\left(R_{i t}-E(R i)\right)\right]^{2}}{n-1}}
$$

4. Coefficient of Variation

$$
\mathrm{CV}=\frac{\sigma_{\mathrm{i}}}{\mathrm{E}\left(\mathrm{K}_{\mathrm{i}}\right)}
$$

\section{METHOD, RESULTS AND DISCUSSION}

\subsection{Research Methodology}

The research used quantitative approach. The variables used are return, risk, and coefficient of variation.

\subsubsection{Type and Source of Data}

Type of data in this research is secondary data. The sources of data that can be accessed are www.idx.co.id, PT BNP Paribas, sukuk, www.goldprice.org, www.syariahmandiri.co.id, www.bi.co.id, several other litelature sources related 
to this research. These data make purposive sampling, that is analyzed for nine years, so the total data in this research was 54 data (Indonesia Stock Exchange, 2017), (Gold Price, 2017), (PT. Bank Syariah Mandiri, 2017), (Bank Indonesia, 2017).

\subsubsection{Operational Definition}

Rate of risk is a measure of the relative deviation of a distribution as the standard deviation ratio with the estimated value for distribution value. The data can be obtained from the expected return and risk in quarterly investment instrument period 2008-2016 using data ratio and it is time series.

\subsection{Results}

Non-probability sampling method with purposive sampling category between JII, NAV per unit BNP Paribas Pesona Syariah, profit's sukuk Ijarah Indosat IV Seri B, gold price, mudharabah deposit with 3 months rate of return, and residential property price index (RPPI).

Table 2: Descriptive Statistic Rate of Risk.

\begin{tabular}{|l|l|l|l|l|}
\hline $\begin{array}{l}\text { Investment } \\
\text { Instrument }\end{array}$ & $\mathrm{N}$ & $\mathrm{Min}$ & $\mathrm{Max}$ & $\mathrm{Mean}$ \\
\hline JII & 9 & $-52,846$ & 1,295 & $-6,616$ \\
\hline $\begin{array}{l}\text { Islamic Mutual } \\
\text { Fund }\end{array}$ & 9 & $-3,577$ & 18,078 & 3,061 \\
\hline Sukuk & 9 & 0,000 & 0,000 & 0,000 \\
\hline Gold & 9 & $-12,065$ & 2,172 & $-0,406$ \\
\hline $\begin{array}{l}\text { Mudharabah } \\
\text { deposit }\end{array}$ & 9 & 0,021 & 0,081 & 0,046 \\
\hline Property & 9 & 0,271 & 1,579 & 0,693 \\
\hline
\end{tabular}

*Data processed

The result of calculation above, the smaller the rate of risk, indicates smaller risk and greater expected return from investment. The statement refers to JII which is the most profitable investment choice.

Table 3: Kolmogorov Smirnov Normality Test.

\begin{tabular}{|l|l|l|l|}
\hline Investment Instrument & Significant & Explain & Examination \\
\hline JII & 0,001 & Not Distributed Normaly & Kruskal-Wallis \\
\hline Islamic Mutual Fund & 0,001 & Not Distributed Normaly & Kruskal-Wallis \\
\hline Sukuk & 0,000 & Not Distributed Normaly & Kruskal-Wallis \\
\hline Gold & 0,001 & Not Distributed Normaly & Kruskal-Wallis \\
\hline Mudharabah deposit & 0,200 & Distributed Normaly & ANOVA \\
\hline Property & 0,200 & Distributed Normaly & ANOVA \\
\hline
\end{tabular}

The table shows not normally distributed test result, except Mudharabah deposits and property. It can be concluded that further risk testing need to use Kruskal-Wallis test.

Table 4. Kruskal-Wallis Test.

\begin{tabular}{|c|c|c|c|c|c|}
\hline Investment Instrument & Mean Rank & Chi-Square & Df & Significant & Explain \\
\hline JII & 23,44 & \multirow{6}{*}{16,492} & \multirow{6}{*}{5} & \multirow{6}{*}{0,006} & \multirow{6}{*}{$\mathrm{H}_{0}$ is rejected } \\
\hline Islamic Mutual Fund & 34,56 & & & & \\
\hline Sukuk & 13,00 & & & & \\
\hline Gold & 36,33 & & & & \\
\hline Mudharabah deposit & 22,00 & & & & \\
\hline Property & 35,67 & & & & \\
\hline
\end{tabular}

*Processed data

The applied significance level is 0,05 which is greater than the risk level of 0,006 . This suggests that there are significant differences ( $\mathrm{H} 0$ rejected). The decision can be seen from the value of bigger statistical calculation and statistical table $(16,492>11,070)$.

\subsection{Discussion}

Comparison of Rate of Return on Islamic Stock, Islamic Mutual Fund, Sukuk, Gold, Mudharabah Deposit, and Property Period 2008-2016

There is a significant difference in investment instruments in according with the above statement that Islamic stocks are at risk both systematically and 
systematically without any intervention from investment managers (Tandelilin, 2010: 104).

In Islamic mutual funds, the risk that occurs in $\mathrm{NAV}$ is influenced by the price of securities that are arranged in its portfolio (decreasing unit value) and liquidity risk that can complicate the company's management in providing its fund (Achsein, 2000:82).

There are risks that must be faced on Sukuk Investment, one of themn is the risk of sharia compliance (Wahid, 2010:296). The risk is due to differences in understanding relating to fiqh and affect the implemented sukuk contract.

According to Oei (2009:65) gold, which is likely to experience a decline in prices, potentially in the case of theft, there will be potentially different price between the selling price and the purchased price.

Based on Financial Authorities Regulation Number 65/POJK.03/2016 clause 1 number 15 which states that rate of return risk is a risk due to changes in the yield rate received by the bank from funds channeling from costumers, that may affect the third party's behavior.

The requirement of property investment is to have a considerable initial capital. It also requires maintenance costs. It will take a considerable amount of time to gain a profit from reselling the investment. (Salim, 2011:6).

\section{CONCLUSIONS}

There were significant difference between rate of risk of islamic stock, islamic mutual fund, sukuk, gold, mudharabah deposit, and property. The significant rate is 0.05 .

Based on the average results in terms of rate of risk, Islamic stock is the best investment instrument among gold, Islamic mutual funds, sukuk, deposit, and property.

Using Kruskal-Wallis test, it can be concluded that rate of risk in Islamic stock, Islamic mutual fund, sukuk, gold, mudharabah deposit, and property is different from each other $\left(\mathrm{H}_{0}\right.$ rejected $)$.

\section{REFERENCES}

Achsien, Iggi H. 2000. Investasi Syariah di Pasar Modal, Menggagas Konsep dan Praktek Manajemen Portofolio Syariah. The First Edition, Jakarta: PT. Gramedia Utama.
Al-Mahali, Imam Jalaluddin dan Imam Jalaluddin AsSuyutti. 2000. Tafsir Jalalain. Jilid 1. Bandung: Sinar Baru Algensindo.

Bank Indonesia. (2017, August 24). Retrieved from Bank Sentral Republik Indonesia: https://www.bi.go.id/id/Default.aspx.

Departemen Agama RI. 1971. Al-Qur'an dan Terjemahnya. Jakarta: Yayasan Penyelenggara Penterjemah/Penafsiran Al-Qur'an.

Gold Price. (2017, August 26). Retrieved from Gold Price .Org: https://goldprice.org/.

Hidayat, Taufik. 2011. Kaya Sekarang Juga! Cara Pintar Investasi Emas \& Dinar. The First Edition. Jakarta: Mediakita.

Indonesia Stock Exchange. (2017, August 26). Retrieved from Bursa Efek Indonesia: www.idx.co.id.

Mansor, Fadillah and M. Ishaq Bhatti. 2011. Risk and Return Analysis on Performance of the Islamic mutual funds: Evidence from Malaysia. Global Economy and Finance Journal. 4 (1): 19.

Mensi, Walid, et.al. 2015. Are Sharia Stocks, Gold and U.S. Treasuries Hedges and Safe Havens for the Oil-Based GCC Markets?. Emerging Markets Review. 24: 101.

Oei, Istijanto. 2009. Kiat Investasi Valas, Emas, Saham. Jakarta: PT Gramedia Pustaka Utama.

PT. Bank Syariah Mandiri. (2017, August 31). Retrieved from Mandiri Syariah: https://www.syariahmandiri.co.id/.

Salim, Joko. 2011. 108 Tanya Jawab Investasi \& Bisnis Properti Kupas Tuntas Strategi Sukses \& Pintar Berinvestasi. Jakarta: Transmedia Pustaka.

Samsul, Mohamad. 2006. Pasar Modal dan Manajemen Portofolio. Jakarta: Erlangga.

Wahid, Nazaruddin Abdul. 2010. Sukuk: Memahami \& Membedah Obligasi pada Perbankan Syariah. Yogyakarta: A-Ruzz Media.

Tandelilin, Eduardus. 2010. Portofolio dan Investasi Teori dan Aplikasi. The First Edition. Yogyakarta: Kanisius.

Yusoff, Wan Zahri Wan, et.al. 2010. A Study of Return on Investment for Commercial Property In Johore State, Malaysia. Construction, Building and Real Estate Research Conference of RICS. (Online) www.researchgate.net accessed on September 12, 2017. 